\title{
Al-Madãris
}

VOL. 2, NO. 1, 2021

E-ISSN: 2745-9950

https://journal.staijamitar.ac.id/index.php/almadaris

\section{ANALISIS INVOICE FINANCING PADA FINTECH SYARIAH (PT. Alami Fintek Sharia)}

\author{
Fitri Salekhah \\ UIN Sunan Kalijaga Yogyakarta \\ Fitrisalekhah137@gmail.com
}

\begin{abstract}
Alami one of the fintech organizer platforms is registered and licensed at the OJK on May 27, 2020 under the company name PT Alami Fintek Syariah which has a Sharia based business type. Invoice financing in Alami is financing in the form of bill management services based on invoice evidence, either with or without a bailout (qard) given to business actors who have invoice to third parties (payor). The performance platform is inseparable from the company's strategy that optimizes sector sector collaboration, industry and business projections, and retail optimization. The success of the Alami platform's performance proves that Alami has won the trust of customers both from funders and also from recipients with a total of 272 existing lists of financing. Product of Alami according to the Fatwa DSN-MUI No. 117/ DSN_MUI/ II/ 2018, because the legal subject has met the requirements, namely there is an organizer (Alami), a recipient of financing (in this case 272 total financing lists) and providers of financing using al qordh and wakalah bil ujrah contracts who have entered into the DSN_MUI fatwa.
\end{abstract}

Keywords: Alami, Fintech Sharia, Invoice Financing, Qard, Wakalah bil Ujrah.

$\overline{\text { Al-Madãris, Volume 2 (1), } 2021}$ 


\section{A. Pendahuluan}

Dunia digital saat ini memiliki peran aktif dalam inovasi perkembangan teknologi sehingga mampu menjadikan aktivitas masyarakat menjadi lebih mudah dan efektif. Industri yang sangat menarik dan sedang mengalami perkembangan yang cukup signifikan adalah industri teknologi keuangan atau lebih dikenal dengan fintech (financial technologi). Munculnya financial technology dalam berbagai platform kini bisa dirasakan oleh masyarakat secara lebih luas. Bank Indonesia memberikan pengertian tentang financial technology atau teknologi finansial yaitu hasil penggabungan antara teknologi dan jasa keuangan yang kemudian mengubah model bisnis dari sistem konvensional menjadi moderat, yang pada awalnya cara pembayaran hanya dapat dilakukan secara langsung dan harus membawa sejumlah uang kas atau tunai tetapi saat ini dapat dilakukan dengan menggunakan transaksi jarak jauh dan juga waktu yang dibutuhkan sangat singkat dalam hitungan detik.

National Digital Research Centre di Dublin, Irlandia juga mendefinisikan financial technology atau fintech sebagai: "innovation in financial services" atau "inovasi dalam layanan keuangan". Financial technology dengan segala bentuk inovasinya pada sistem layanan keuangan tidak hanya dapat dikembangkan pada sektor swasta saja, melainkan juga kehidupan bernegara (Nurcahya \& Dewi, 2019). Teknologi digital yang merupakan inovasi baru dalam kegiatan ekonomi tentu saja dapat mempengaruhi berbagai macam sektor seperti pertanian, perdagangan dan secara khusus pada sektor keuangan. Fintech telah mendapatkan perhatian secara luas sebagai teknologi menantang yang akan memberdayakan perusahaan untuk bersaing dengan efektif pada abad dua puluh satu saat ini. Pemerintah didunia telah memberikan perhatian mengenai tantangan dan juga merancang kebijakan serta peraturan untuk mendukung perkembangan fintech (Yarli, 2018).

Perkembangan fintech di Indonesia sendiri sangat terlihat jelas. Pada awalnya hanya terdapat 4 perusahaan saja yaitu di tahun 2006 dan kemudian berkembang menjadi 16 perusahaan di tahun 2007. Perkembangan yang signifikan terjadi pada tahun 2015 hingga 2016 dimana jumlah perusahaan yang menjalankan model bisnis fintech sekitar 165 perusahaan (Parizi, 2019). Selanjutnya pertumbuhan fintech berdasarkan data yang terdaftar di OJK (Otoritas Jasa Keuangan) sampai dengan 28 Desember 2020 memiliki jumlah total penyelenggara fintech terdaftar dan berizin adalah sebanyak 161 perusahaan dimana sebanyak 149 jenis usahanya konvensional, 12 jenis usahanya berdasarkan syariah.

Melihat fenomena yang ada dan berkembang saat ini banyak terdapat adanya lembaga keuangan yang menggunakan prinsip syariah, begitu juga dengan lembaga fintech yang juga menggunakan prinsip syariah baik yang sudah terdaftar dalam OJK ataupun masih dalam tahap proses. Prospek industri fintech syariah di Indonesia sebagai negara berpenduduk muslim terbesar di dunia tentunya sangat menarik perhatian masyarakat.

Fintech syariah sebagai lembaga keuangan dalam penerapannya harus sesuai dengan prinsip-prinsip syariah yang terhindar dari Maysir, Gharar dan Riba. Pelaksanaan fintech Syariah di Indonesia mulai mendapat perhatian dari pemerintah dengan dikeluarkannya Fatwa berkaitan dengan Fintech Syariah oleh Dewan Syariah Nasional Majelis Ulama Indonesia (DSN-MUI) Nomor 117/DSN-

Al-Madãris, Volume 2 (1), 2021 
MUI/II/2018 tentang Layanan Pembiayaan Berbasis Teknologi Informasi berdasarkan Prinsip Syariah. Dengan adanya Fatwa tersebut maka diharapkan perkembangan fintech syariah di Indonesia semakin signifikan, tetapi kemudian yang menjadi permasalahan adalah banyaknya lembaga fintech konvensional sebelumnya yang memberikan kesan kurang baik dengan adanya berbagai macam pemberitaan dan juga stigma negatif pada pelaksanaan fintech yang terjadi pada masyarakat (Hiyanti et al, 2019). Kehadiran beberapa penyelenggara fintech yang berlandaskan pada prinsip syariah tentunya diharapkan mampu untuk memperbaiki tujuan awal dari berdirinya fintech yang seharusnya memudahkan kehidupan masyarakat dalam melaksanakan berbagai macam kegiatan dan transaksi ekonomi.

Salah satu produk yang ditawarkan oleh fintech syariah adalah invoice financing atau pembiayaan tagihan. Invoice financing merupakah suatu usaha pembiayaan dalam bentuk pembelian atau pengalihan piutang atau tagihan jangka pendek suatu perusahaan dari transaksi perdagangan dalam atau luar negeri. Fatwa DSN MUI Nomor 117/ DSN-MUI/II/2018 menyatakan bahwa pembiayaan anjak piutang (factoring) adalah pembiayaan dalam bentuk jasa pengurusan penagihan piutang berdasarkan bukti tagihan (invoice), baik diserta talangan (qardh) yang diberikan kepada pelaku usaha yang memiliki tagihan kepada pihak ketiga (payor). Fintech Syariah memberikan invoice financing (anjak piutang) menggunakan akad Qard dan wakalah bil ujrah, tetapi dalam tataran praktek dilapangan kesyariahan sebuah produk masih dipertanyaan kesesuaiannya dengan prinsip-prinsip dari Fatwa DSN MUI.

Berdasarkan latar belakang tersebut diatas, maka tujuan dari penulisan ini adalah untuk mengetahui bagaimana implementasi akad qard dan wakalah bil ujroh pada invoice financing di Fintech Syariah dalam hal ini adalah platform Alami dan juga untuk mengetahui klasifikasi invoice financing ditinjau berdasarkan Fatwa DSN-MUI Nomor 117/ DSN-MUI/II/2018 mengenai layanan pembiayaan berbasis teknologi informasi berdasarkan prinsip Syariah.

\section{B. Review Literatur}

Fintech atau finansial teknologi adalah teknologi yang berkaitan dengan keuangan yang kemudian berinovasi sehingga terdapat solusi baru yang menunjukkan pengembangan dalam berbagai hal seperti produk, aplikasi dan juga model bisnis di industri jasa keuangan (Chuen \& Low, 2018). Pada umumnya perusahaan lembaga keuangan fintech adalah perusahaan start-up yang mana perusahaan tersebut menawarkan produk layanan keuangan dan juga merupakan solusi keuangan untuk masyarakat yang kemudian diaplikasikan dalam berbagai bentuk produk-produk yang mencakup produk pembayaran mobile, transaksi transfer uang, pinjaman ataupun dapat berupa manajamen asset yang telah ditawarkan oleh lembaga keuangan fintech tersebut.

Fenomena saat ini yang terdapat pada lembaga keuangan berdasarkan prinsip syariah mulai mencuri perhatian publik. Tidak terkecuali bagi para pemilik bisnis di industri keuangan, tetapi juga bagi masyarakat secara umum. Di dunia fintech mulai muncul berbagai macam startup yang melakukan pendanaan dan juga praktik investasi yang menggunakan prinsip syariah. Di Asia Tenggara, terdapat dua fintech syariah terbesar yaitu Ethis Crowd dan Kapital Boost. Al-Madãris, Volume 2 (1), 2021 
Produk atau layanan transaksi yang ditawarkan oleh fintech tidak hanya untuk kepentingan komersial tetapi juga menyediakan fasilitas bagi orang-orang yang ingin berbagi kepada yang lebih membutuhkan dengan menjadi donatur untuk berbagai macam kegiatan amal. Di Indonesia, progres pengembangan fintech syariah memiliki peluang yang sangat luas dan baik, karena saat ini belum banyak pemilik usaha bisnis yang mendirikan fintech berdasarkan prinsip syariah. Indonesia sendiri merupakan salah satu pangsa pasar yang terbesar untuk layanan transaksi produk berbasis syariah (Wijayanti \& Riza, 2017).

Layanan transaksi yang sesuai atau berdasarkan dengan syariat Islam tentunya harus yang berlandaskan kepada al-Quran dan Hadis. Segala macam bentuk perekonomian dan juga transaksi usaha bisnis menurut ajaran Islam yang bersumber dari al-Quran dan Sunnah adalah untuk memperhatikan keadilan hak individu yang harus terlindungi dan juga sekaligus untuk menegakkan rasa solidaritas atau kebersamaan yang tinggi terhadap masyarakat sesama. Pada dasarnya beberapa akad yang terdapat dalam layanan transaksi fintech tidak bertentangan selagi tidak bertentangan juga dengan prinsip syariah. Selain itu, Fintech juga merujuk berdasarkan kepada salah satu asas yang ada di muamalah yaitu an-taradhin yang memiliki makna saling ridho, ikhlas atau saling suka diantara kedua belah pihak, atas dasar asas muamalah tersebut maka akad atau transaksi yang terjadi diantara kedua belah pihak tersebut menjadi sah (Arner, 2016).

Keputusan Dewan Syariah Nasional Majelis Ulama Indonesia (DSN MUI) menetapkan fatwa No: 117/DSN-MUI/II/2018 tentang Layanan Pembiayaan Berbasis Teknologi Informasi Berdasarkan Prinsip Syariah. Hal ini dilakukan sebagai bentuk perhatian dalam hal transaksi layanan pembiayaan berbasis teknologi untuk pelaku usaha skala mikro, kecil dan menengah (UMKM) sebagai upaya dalam mendapatkan akses pendanaan yang lebih cepat, mudah dan juga lebih efisien. Masyarakat di Indonesia sangat memerlukan penjelasan mengenai berbagai macam ketentuan dan batasan hukum yang terkait dengan layanan pembiayaan berbasis teknologi informasi berdasarkan prinsip syariah. DSN-MUI menetapkan fatwa yang berkaitan tentang layanan pembiayaan berbasis teknologi informasi berdasarkan prinsip syariah untuk dijadikan sebagai pedoman invoice financing sebagai berikut:

1. Adanya akad yang menimbulkan hubungan hukum utang piutang yang ditunjukkan dengan bukti tagihan (invoice) oleh calon penerima pembiayaan dari pihak ketiga (payor) yang menjadi dasar jasa dan/atau pembiayaan anjak piutang.

2. Calon penerima pembiayaan atas dasar bukti tagihan (invoice) yang dimiliki, mengajukan jasa dan/atau pembiayaan kepada penyelenggara.

3. Penyelenggara menawarkan kepada calon pemberi pembiayaan untuk memberikan jasa penagihan piutang berdasarkan bukti tagihan (invoice), baik disertai atau tanpa disertai talangan (qardh).

4. Dalam hal calon pemberi jasa dan/atau pembiayaan menyetujui penawaran dilakukan akad wakalah bil ujrah antara pemberi pembiayaan dengan penyelenggara; pemberi pembiayaan sebagai muwakkil, dan penyelenggara sebagai wakil. 
5. Penyelenggara melakukan akad wakalah bi al-ujrah dengan penerima Pembiayaan untuk penagihan utang; Penyelanggara sebagai wakil, dan Penerima Pembiayaan sebagai muwakkil.

6. Penyelenggara sebagai wakil dari pemberi pembiayaan dapat memberikan talangan dana dengan akad qardh kepada penerima pembiayaan/Jasa.

7. Penyelenggara melakukan penagihan kepada pihak ketiga (payor) atas piutang penerima pembiayaan.

8. Penerima pembiayaan membayar ujrah kepada Penyelenggara.

9. Penerima pembiayaan membayar utang qardh (jika ada) kepada penyelenggara sebagai wakil.

10. Penyelenggara wajib menyerahkan ujrah dan qardh (jika ada) kepada pemberi pembiayaan.

Akad-akad yang digunakan dalam layanan pembiayaan berbasis teknologi berdasarkan prinsip syariah antara lain adalah Akad jual beli/murabahah, Ijarah, Musyarakah, Mudharabah, Qardh, Wakalah dan akad Wakalah bil Ujrah. Akad Qard merupakan salah satu akad yang termasuk dalam Akad Kedermawanan (Uqud Ghair Al-Mu'awadah) yang mempunyai karakteristik utama adalah untuk menyumbangkan harta benda (Ayub, 2009: 195). Qardhul Hasan dapat diartikan sebagai pinjaman yang mempersyaratkan adanya imbalan, waktu penetapan pinjmaan ditetapkan bersama antara pemberi dan penerima pinjaman. Akad AlWakalah berarti kontrak yang menentukan jangka pemberian kuasa dari satu pihak ke pihak yang lain (Rusdiana \& Saptaji, 2018: 68). Akad Wakalah bi alujrah menurut Fatwa DSN MUI yaitu akad wakalah yang disertai dengan imbalan berupa ujrah (fee). Penelitian yang dilakukan oleh Darmawansyah \& Aguspriyani (2019) meneliti konsep fatwa DSN-MUI No: 117/DSN-MUI/II/2018 tentang Layanan Pembiayaan Berbasis Teknologi Informasi Berdasarkan Prinsip Syariah di PT. Investree. Hasil penelitian menuliskankan bahwa Investree melakukan inovasi dengan mengeluarkan produk berbasis syariah yang dikeluarkan sejak akhir tahun 2017. Beberapa produknya yaitu pembiayaan usaha syariah atau invoice financing syariah dan pembiayaan modal kerja (online seller financing sharia). Produk invoice financing ini sudah sesuai dengan Fatwa DSNMUI No.117/DSN-MUI/II/2018 karena produk invoice financing ini sama dengan anjak piutang/factoring. Produk Pemberian Modal Kerja juga sudah sesuai dengan Fatwa DSN-MUI No.117/DSN-MUI/II/2018.

Penelitian yang dilakukan oleh Maulida et al (2020) tentang implementasi akad pembiayaan qard dan wakalah bil ujrah pada platform fintech lending syariah ditinjau berdasarkan peraturan otoritas jasa keuangan (OJK) dan fatwa DSN-MUI. Hasil penelitian menunjukkan bahwa sistem informasi dengan invoice financing syariah yang digunakan oleh Platform Investree Syariah sudah sesuai ditinjau berdasarkan tinjauan POJK No. 77 /POJK.01/2016, Implementasi akad Al qordh yang digunakan sudah sesuai ditinjau berdasarkan Fatwa DSN-MUI No. 19/DSN-MUI/IV/2001 mengenai AlQardh. Implementasi akad Wakalah bil Ujrah yang digunakan sudah sesuai ditinjau berdasarkan Fatwa DSN-MUI No. 113/DSN-MUI/IX/2017 mengenai Akad Wakalah Bi Al-Ujrah. Klasifikasi akad Qardh dan Wakalah bil Ujrah yang digunakan menggunakan model Pembiayaan anjak piutang (factoring) ditinjau berdasarkan Fatwa Dewan Syariah Nasional 
Majelis Ulama Indonesia No. 117/DSN-MUI/II/2018 Tentang Layanan Pembiayaan Berbasis Teknologi Informasi Berdasarkan Prinsip Syariah.

Penelitian yang dilakukan oleh Wiyono (2020) meneliti tentang mekanisme dan layanan peer-to-peer lending syariah perspektif ekonomi islam (studi analisis pada 13 fintech syariah yang terdaftar di otoritas jasa keuangan per 19 februari 2020. Hasil penelitian menjelaskan bahwa mekanisme dan layanan Peer-To-Peer Lending Syariah dari 13 Fintech Syariah yang Terdaftar di Otoritas Jasa Keuangan Per 19 Februari 2020 secara garis besar sudah sesuai dengan prinsip-prinsip Ekonomi Islam. Tidak ditemukan unsur yang dilarang dalam Ekonomi Islam diantaranya maisir, gharar, dan riba, dst, serta menaati Fatwa DSN MUI Nomor 117/DSN-MUI/II/2018 Tentang Layanan Pembiayaan Berbasis Teknologi Informasi Berdasarkan Prinsip Syariah, serta fatwa-fatwa yang relevan lainnya.

Penelitian yang dilakukan oleh Alwi (2018) tentang pembiayaan berbasis teknologi informasi (fintech) yang berdasarkan syariah menunjukkan bahwa layanan fintech berbasis syariah selain memberikan penawaran dan skema yang berbeda dari layanan yang sudah ada, juga memberikan pembatasan tertentu terhadap penggunaan dana yang diberikan oleh investor atau pemberi pinjaman. Permintaan pengguna jasa layanan fintech berbasis syariah yang meningkat yang didukung dengan pangsa pasar pengguna layanan dari masyarakat Indonesia yang mayoritas muslim mendorong Layanan Fintech berbasis syariah wajib memenuhi kaidah kaidah dalam transaksi bisnis secara syariah.

Penelitian yang dilakukan oleh Pratama (2020) tentang faktor-faktor yang mempengaruhi preferensi masyarakat menggunakan jasa teknologi keuangan di lembaga keuangan Syariah menunjukkan bahwa pengguna fintech syariah memiliki persepsi mengenai kemudahan bertransaksi, persepsi yang berkaitan dengan berbagai macam manfaat yang diberikan dan juga sikap yang ditunjukkan oleh para SDM mempengaruhi preferensi masyarakat dalam menggunakan layanan teknologi keuangan berdasarkan prinsip syariah.

Lestari (2019) meneliti tentang tinjauan Kompilasi Hukum Ekonomi Syariah terhadap pembiayaan peer to peer lending pada Lembaga Kapitalboost. Hasil penelitian menunjukkan bahwa Kedudukan hukum peer to peer lending pada lembaga Kapitalboost di Indonesia secara legalitas, kapitalboost telah memiliki Sertifikat Kepatuhan Syariah dari Financial Shariah Advisory Dan Consultancy (FSAC) di Singapura. Hukum pembiayaan peer to peer lending pada lembaga Kapitalboost ditinjau dari Kompilasi Hukum Ekonomi Syariah Operasional dalam sistem pembiayaan murabahah pada Financial Technology berbasis syariah pada Kapitalboost telah sesuai dengan kompilasi hukum ekonomi syariah. Pembiayaan Faktur (Qard dan Wakalah) pada Financial Technology berbasis syariah pada Kapitalboost telah sesuai dengan kompilasi hukum ekonomi syariah.

Penelitian yang dilakukan oleh Baihaqi (2018) bertujuan untuk menjelaskan konsep online peer-to-peer lending berdasarkan aturan syariah. Hasil penelitian menunjukkan bahwa peer-to-peer lending online diperbolehkan dalam hukum Islam yang bebas dari transaksi terlarang, menggunakan akad syariah, transparan, dan berkeadilan. Terdapat enam (6) model peer-to-peer lending online yang dapat dilakukan sesuai Fatwa DSN-MUI yaitu pembiayaan anjak piutang, pembiayaan pengadaan barang pesanan, pembiayaan penjual online, pembiayaan Al-Madãris, Volume 2 (1), 2021 
online penjual melalui payment gateway, pembiayaan karyawan, dan pembiayaan berbasis komunitas.

\section{Metodelogi}

Metode yang digunakan dalam penelitian ini adalah penelitian kualitatif dengan pendekatan deskriptif. Data pada penelitian ini menggunakan data sekunder, yaitu berupa bahan hukum primer (primary source), dan bahan hukum sekunder (secondary source) yang diperoleh dari laman resmi PT. Alami Fintek Sharia dan juga berasal dari jurnal-jurnal yang berkaitan dengan masalah penelitian. Teknik pengumpulan data yang digunakan adalah studi kepustakaan.

Analisis dilakukan secara kualitatif tentang implementasi norma hukum agama yang dikeluarkan oleh Fatwa DSN-MUI No. 117/DSN-MUI/II/2018 mengenai Layanan Pembiayaan Berbasis Teknologi Informasi Berdasarkan Prinsip Syariah, Adapun objek yang digunakan dalam penelitian ini hanya terbatas kepada salah satu produk yang dikeluarkan oleh perusahaan fintech Syariah yaitu platform Alami dalam bentuk pembiayaan kepada beneficiary oleh Funder dengan menggunakan 2 (dua) akad yaitu akad Al qardh dan Wakalah bil Ujrah.

\section{Hasil Penelitian}

Alami merupakan salah satu platform penyelenggara Fintech terdaftar dan berizin di OJK pada tanggal 27 Mei 2020 dengan mana perusahaan PT Alami Fintek Sharia dengan memiliki jenis usaha berbasis Syariah. Invoice financing di Alami merupakan pembiayaan dalam bentuk jasa jasa pengurusan penagihan piutang berdasarkan bukti tagihan (invoice), baik disertai atau tanpa disertai talangan (qard) yang diberikan kepada pelaku usaha yang memilii tagihan kepada pihak ketiga (payor).

Cara mengajukan pembiayaan melalui platform Alami:

1. Invoice sudah siap dibayar

Sebagai calon penerima dana di Alami atau beneficiary, memastikan telah menyelesaikan proses transaksi dan penagihan ke pihak payor.

2. Mengajukan invoice ke platform Alami

Invoice yang diajukan akan dicarikan pihak yang bersedia memberikan jasa factoring.

3. Pemeriksaan dokumen oleh platform Alami

Tim Risk Alami melakukan tahapan pemeriksaan dokumen dan Credit Scoring.

4. Alami membantu mencaikan pendana Jika sudah disetujui, Alami akan mencarikan pendana untuk pembiayaan.

5. Pembiayaan akan didanai oleh pendana

Saat pembiayaan sudah berhasil didanai, danayang sudah dikumpulkan akan segera dicairkan/ disalurkan.

6. Pengembalian pendanaan serta ujrah

Pada akhir periode pembiayaan pihak payor akan membayarkan tagihannya langsung ke Alami yang nantiny akan dikembalikan ke pendana beserta ujrah dari pembiayaan.

Alami akan menerima pengajuan pendanaan anjak piutang dari UKM pada platform. Alami kemudian akan melakukan credit scoring terhadap UKM yang 
mengajukan. Credit scoring didasarkan pada Analisa kualitatif dan kuantitatif. Analisa kuantitatif didasarkan pada laporan keuangan dan rekening koran, sedangkan analisa kualitatif didasarkan pada Riwayat historis dan juga Analisa kunjungan ke tempat usaha. Setelah mendapatkan hasil skoring, alami akan memberikan penawaran perjanjian pembiayaan. Permohonan pembiayaan akan segera masuk ke dalam listing dalang jangka waktu paling lambat 14 hari kerja. Setelah dana terkumpul maka akan segera disalurkan kepada UKM bersangkutan dan pelunasan akan dilaksanakan sesuai dengan jatuh tempo yang dijanjikan.

Invoice financing atau anjak piutang (factoring) merupakan suatu usaha pembiayaan dalam bentuk pembelian atau pengalihan serta pengurusan piutang atau tagihan jangka pendek suatu perusahaan dari transaksi perdagangan dalam atau luar negeri. Anjak piutang (factoring) secara Syariah dapat merujuk pada Fatwa DSN No: 117/ DSN-MUI/II/2018 yang menyatakan pembiayaan anjak piutang (factoring) adalah pembiayaan dalam bentuk jasa pengurusan penagihan piutang berdasarkan bukti tagihan (invoice), baik disertai atau tanpa diserta talangan (qard) yang diberikan kepada pelaku usaha yang memiliki tagihan kepada pihak ketiga (payor).

Skema Invoice Financing di Alami:

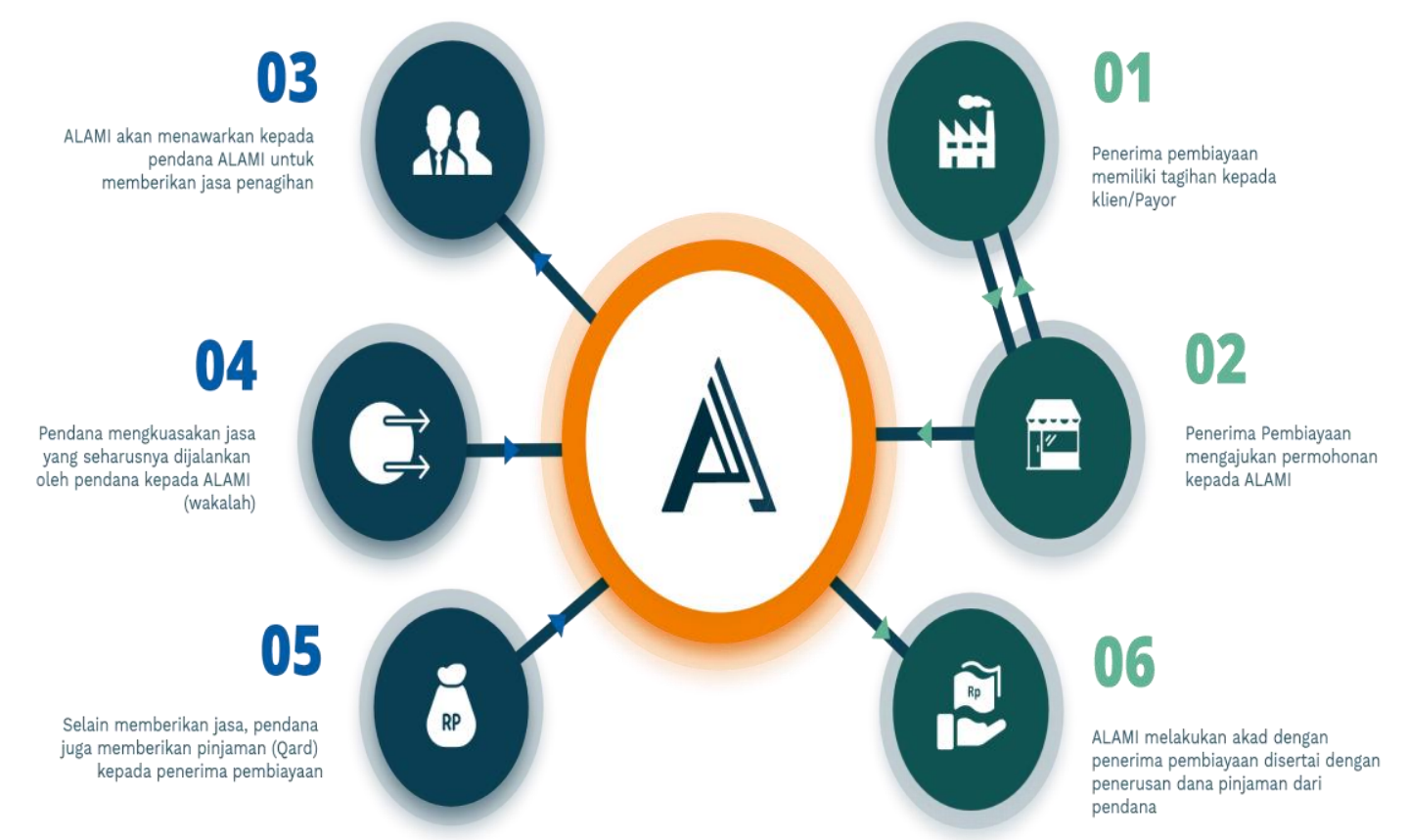

Gambar 1. Skema Invoice Financing Alami

1. Penerima pembiayaan memiliki tagihan kepada klien/ payor (hubungan muamalah) yang menyebabkan penerima pembiayaan memiliki hak tagih dan mengelola dokumen.

2. Penerima pembiayaan mengajukan permohonan kepada Alami untuk mencarikan pihak yang bersedia memberikan jasa pengelolaan dokumen dan penagihan. 
3. Alami akan menawarkan kepada pendana Alami untuk memberikan jasa penagihan dan pengelolaan dokuen yang mana atas hal ini akan diberikan suatu imbalan (wakalah bil ujrah)

4. Pendana menguasakan jasa yang seharusnya dijalankan oleh pendana kepada Alami (wakalah)

5. Selain memberikan jasa pendana juga memberikan pinjaman (qard) kepada penerima pembiayaan

6. Alami sebagai kuasa pendana melakukan akad dengan penerima pembiayaan disertai dengan penerusan dana pinjaman dari pendana.

Kriteria Pemberi Pendanaan:

1. Warga Negara Indonesia (WNI) berusia minimal 17 tahun, memiliki KTP dan NPWP.

2. Warga Negara Asing (WNA) berusia minimal 17 tahun, memiliki paspor dan rekening an. Pemberi dana.

3. Minimum pendanaan sebesar RP. 1 juta dan berlaku kelipatan

4. Alami tidak mengenakan biaya pada pendana atas pendanaan yang dilakukan

5. Pajak dikenakan pada pendana sesuai dengan ketentuan yang berlaku.

Pendana dikenakan pajak berdasarkan penerimaan ujrah pada saat repayment, dengan nilai pajak sesuai dengan ketentuan perpajkan yang berlaku. Nantinya penerima pembiayaan akan membayar pajak dan bukti potong pajak bisa dilihat di dashboard pendana.

Kriteria Penerima Pendanaan:

1. UKM berbadan usaha PT atau CV

2. Semua sector industry kecuali Rokok, Miras, Alkohol. Dan Makanan Haram

3. Minimum telah menjalankan usaha selama 1 tahun.

Produk pembiayaan Alami:

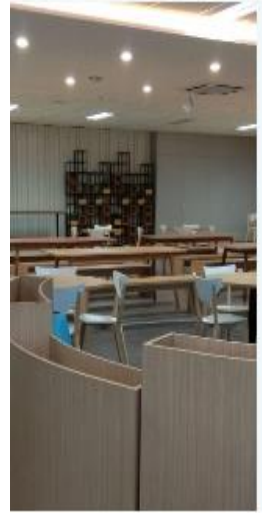

JTK

Perdagangan Kecil Makanan

Total Pembiayaan

(Rp)

88.000 .000

Imbal Hasil/Ujrah

(Setara)

$16.59 \%$

Jatuh Tempo

Februari 21

2021

Terdanai : $100.00 \%$ | Slot $(R p) 0$

Gambar 2. Produk pembiayaan Alami Terdanai 100\%

$\overline{\text { Al-Madãris, Volume 2 (1), } 2021}$ 


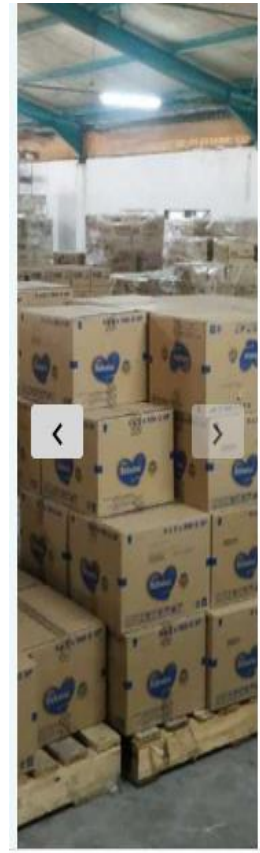

$\begin{array}{ll}\text { Jumlah Pembiayaan } & \text { Slot Pendanaan } \\ \text { Rp 1.732.500.000 } & \text { Rp 1.732.500.000 } \\ \text { Imba| Hasil/Ujrah (Setara) } \boldsymbol{O} & \text { Jatuh Tempo } \\ \text { 13.00\% p.a. } & 20 \text { Mei 2021 } \\ \text { Imba| Hasil/Ujrah dari Invoice } \boldsymbol{O} & \text { Tenor } \\ \text { 13.00\% p.a. } & 116 \text { Hari }\end{array}$

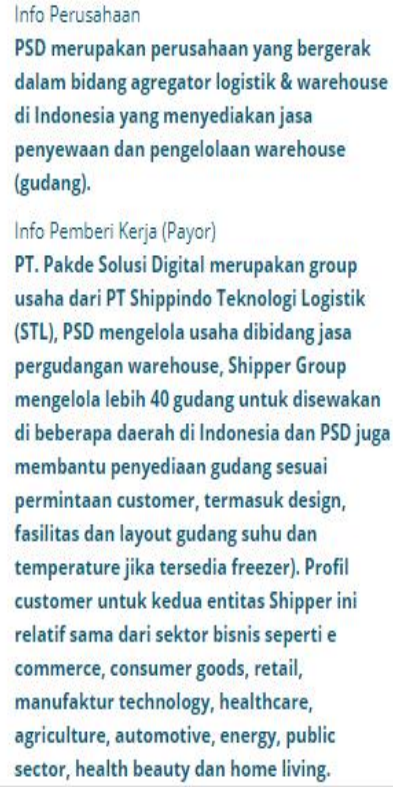

Gambar 3. Produk pembiayaan Alami yang belum Terdanai

Pada gambar produk pembiayan diatas, range ujrah sudah ditentukan dari awal oleh Alami. Setiap pengajuan pembiayaan, penerima pembiayaan nantinya akan dinilai melalui Risk Assesment Criteria dari tim Alami yang dimana menjadi patokan ujrah yang bisa dijadikan pendana atas setiap pembiayaan yang diberikan. Alami memberikan produk pembiayaan usaha berdasarkan prinsip syariah atau dalam hal ini disebut dengan invoice financing. Produk Invoice financing adalah produk pembiayaan yang dibuktikan dengan tagihan atau invoice, dalam hal ini Alami akan menawarkan kepada pendana Alami untuk memberikan jasa penagihan dan pengelolaan dokumen yang mana atas hal ini akan diberikan suatu imbalan (wakalah bil ujrah) sebagai dasar dalam pengambilan keuntungan oleh Lender. Invoice financing yang disiapkan oleh payor adalah salah satu jaminan dalam bentuk invoice. Pendana menguasakan jasa yang seharusnya dijalankan oleh pendana kepada Alami dengan menggunakan akad wakalah. Selain memberikan jasa, pendana juga memberikan pinjaman (qard) kepada penerima pembiayaan (dalam hal ini adalah UKM).

\section{E. Pembahasan}

Penerapan akad qard harus sesuai dengan prinsip syariah yang telah ditentukan oleh DSN-MUI. Produk invoice financing pada platform Alami telah menggunakan akad al qardh ini sesuai dengan Fatwa DSN-MUI No. 19/DSNMUI/IV/2001 karena jelas al qordh diberikan kepada nasabah (UKM) yang benarbenar memerlukan dengan tidak memberikan presentasi tambahan pengembalian atas pinjaman yang diberikan oleh Lender, pada pembiayaan invoice financing ini Alami telah menjelaskan waktu jatuh tempo dimana payor wajib mengembalikan semua dana yang dipinjam kepada Lender.

Implementasi Fatwa DSN-MUI No: 117/DSN-MUI/II/2018 mengenai Layanan Pembiayaan Berbasis Teknologi Informasi Berdasarkan Prinsip Syariah

Al-Madãris, Volume 2 (1), 2021 
Pada tahun 2018 merupakan momentum bagi perusahaan fintech syariah, karena pada tahun tersebut perusahaan fintech syariah mendapatkan fatwa dari DSNMUI yang artinya produk yang diterapkan oleh Alami telah sesuai dengan prinsip Syariah. Penyelenggara fintech Syariah PT Alami Fintek Sharia (Alami) telah menyalurkan akumulasi pembiayaan sebesar Rp 280 Miliar hingga November 2020. Meski adanya pandemi covid-19, Alami mampu menjaga tingkat keberhasilan pembayaran (TKB) 90 hari di level $100 \%$ (https://keuangan.kontan.co.id/).

Kinerja platform Alami tidak terlepas dari strategi perusahaan yang mengoptialkan kolaborasi lintas sector, proyeksi industry dan bisnis, serta optimalisasi pendana ritel. Saat ini Platform Alami berupa pendanaan invoice financing yang ditargetkan ke industry-industri yang defensive terhadap Covid19, antara lain makanan, ogistik dan Kesehatan. Keberhasilan dari kinerja platform Alami membuktikan bahwa Alami telah mendapatkan kepercayaan dari nasabah baik dari pihak funder dan juga dari pihak beneficiary dengan jumlah 272 daftar pembiayan yang ada.

272 Daftar Pembiayaan

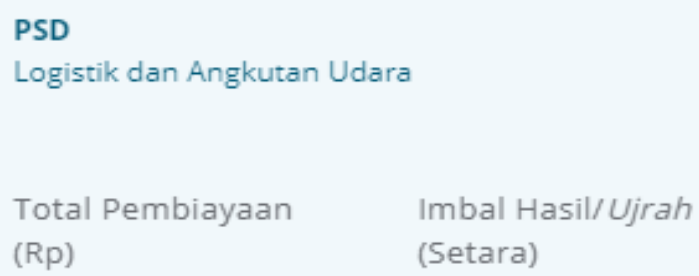

Imbal Hasil/Ujrah (Setara)

\section{$13.00 \%$}

Jatuh Tempo

Mei 202021

Terdanai : $50.60 \%$ | Slot $(R p) 988.000 .000$

\section{Gambar 4. Daftar Pembiayaan Alami}

\section{F. Kesimpulan}

Produk Alami sesuai dengan Fatwa DSN-MUI No. 117/DSN-MUI/II/2018, karena secara subyek hukum telah memenuhi syarat yaitu terdapat penyelanggara (Alami), penerima pembiayaan (dalam hal ini 272 jumlah daftar pembiayaan) dan pemberi pembiayaan (funder) dengan menggunakan akad al qordh dan Wakalah bil Ujrah yang telah disebutkan dalam fatwa DSN tersebut. Model layanan pembiayaan yang digunakan berbasis teknologi dan informasi menggunakan model Pembiayaan anjak piutang (factoring) karena dalam menyalurkan pembiayaan pada salah satu produk platform Alami berbentuk jasa karena telah melakukan pengurusan penagihan piutang berdasarkan bukti tagihan (invoice), dengan disertai talangan (qardh) yang diberikan kepada pihak pelaku usaha yang memiliki tagihan kepada pihak ketiga (Payor). Pada skema mekanisme pembiayaan Alami telah sesuai karena pada akad ini borrower $\overline{\text { Al-Madãris, Volume 2 (1), } 2021}$ 
mengajukan jasa dan/atau pembiayaan kepada pihak Alami dengan melampirkan penagihan piutang berdasarkan bukti tagihan (invoice), yang kemudian oleh Alami yang bertindak sebagai wakil diteruskan kepada calon pemberi jasa atau Funder. Ketika jatuh tempo atas jasa Funder maka pihak penyelenggara atau Alami wajib memberikan Ujrah dan Qardh yang telah ditentukan sejak perjanjian awal.

\section{BIBLIOGRAFI}

Alwi, Ahmad Basori. (2018). Pembiayaan Berbasis Teknologi Informasi (Fintech) yang Berdasarkan Syariah. Al-Q̄ānūn, Jurnal Pemikiran dan Pembaharuan Hukum Islam, (21)2.

Arner. 2016. Opportunities and Challenges, Fintech and Regtech.

Ayub, Muhammad. (2009). Understanding Islamic Finance. Jakarta: Gramedia Pustaka Utama.

Baihaqi, Jadzil. (2018). Financial Technology Peer-To-Peer Lending Berbasis Syariah di Indonesia. Tawazun, (l)2.

Chuen, David Lee Kuo \& Low, Linda. (2018). Inclusive Fintech (Blockhain, Cryptocurrency and ICO). New York: Worid Scientific.

Darmawansyah \& Aguspriyani. (2019). Implementation Of Fintech Syariah In PT. Investree Reviewed Based On Fatwa DSN-MUI No: 117 / DSN-MUI / II / 2018 About Information Technology-Based Financing Services Based On Sharia Principles. Ad-Deenar, (3) 2 .

Fatwa DSN MUI No: 117/DSN-MUI/II/2018

Hiyanti, Hida. Nugroho, Lucky. Sukmadilaga, Citra \& Fitrijanti, Tettet. (2019). Peluang dan Tantangan Fintech (Financial Technologi) Syariah di Indonesia. Jurnal Ilmiah Ekonomi Islam, (5)3. http://dx.doi.org/10.29040/jiei.v5i3.578.

https://keuangan.kontan.co.id/

https://p2p.alamisharia.co.id/id/pembiayaan

Lestari, Dikta Ayu. (2019). Tinjauan Kompilasi Hukum Ekonomi Syariah Terhadap Pembiayaan Peer To Peer Lending Pada Lembaga Kapitalboost (Thesis). Universitas Islam Negeri Maulana Malik Ibrahim, Malang, Indonesia.

Maulida, Sri. Hasan, Ahmadi. \& U Umar, Masyitah. (2020). Implementasi Akad Pembiayaan Qard dan Wakalah bil Ujrah pada Platform Fintech Lending Syariah ditinjau Berdasarkan Peraturan Otoritas Jasa Keuangan (OJK) dan Fatwa DSN-MUI. Al-Tijary Jurnal Ekonomi dan Bisnis Islam, (5)2.

Nurcahya, Yulida Army \& Dewi, Rizky Puspita. (2019). Analisis Pengaruh Perkembangan Fintech dan E-Commerce terhadap Perekonomian Masyarakat. Universitas Tidar: Magelang.

Ojk.go.id

Parizi, Ahmat. (2019). Perkembangan Fintech Syariah. Kseiprogres.com

Pratama, Ahmad Aziz Putra. (2020). The Factors that Influence the Community Preference Using Financial Technology Services in Sharia Financial Institutions. Falah: Jurnal Ekonomi Syariah, (5)1.

$\overline{\text { Al-Madãris, Volume 2 (1), } 2021}$ 
Rusdiana, A. \& Saptaji, Aji. (2018). Auditing Syariah, Akuntabilitas Sistem Pemeriksaan laporan Keuangan. Bandung: Pustaka Setia.

Wijayanti, Dwi Marlina \& Riza, Alex Fahrur. (2017). Sharia Fintech: Positive Innovation in Consumer Perspective. KPPU, Proceeding International Seminar on Competition Policy and Law. Nusa Dua, Bali.

Wiyono, Teguh. (2020). Mekanisme dan Layanan Peer-To-Peer Lending Syariah Perspektif Ekonomi Islam (Studi Analisis pada 13 Fintech Syariah yang Terdaftar di Otoritas Jasa Keuangan Per 19 Februari 2020) (Theses). IAIN Ponorogo, Ponorogo, Indonesia.

Yarli, Dodi. (2018). Analisis Akad Tijarah pada Transaksi Fintech Syariah dengan Pendekatan Maqhasid. Jurnal Pemikiran dan Hukum Islam Yudisia, (9)2. 